Journal Club

Editor's Note: These short, critical reviews of recent papers in the Journal, written exclusively by graduate students or postdoctoral fellows, are intended to summarize the important findings of the paper and provide additional insight and commentary. For more information on the format and purpose of the Journal Club, please see http://www.jneurosci.org/misc/ifa_features.shtml.

\title{
Bridging the Gap between DNA Methylation, DNA Methylation Readers, and Neurodevelopmental Disorders
}

\author{
() Heather McGowan \\ Department of Neuroscience and Cell Biology, Graduate School of Biomedical Sciences New Brunswick/Piscataway, Robert Wood Johnson Medical School, \\ Rutgers, the State University of New Jersey, New Brunswick, New Jersey 08903 \\ Review of Sharma et al.
}

The epigenome consists of covalent modifications made to DNA and histones, as well as regulatory signaling mediated by RNA molecules, that result in transient, developmental, or stably inherited changes in chromatin structure and genomic function. The processes that mediate these changes enable cells containing identical copies of the entire genome to develop highly specialized functions based on the selective expression of specific genes. Thus, epigenetic modifications are essential to developmental processes, such as cellular differentiation, X-inactivation, genomic imprinting, and aging. Perturbations in the epigenetic landscape have been implicated in pathological processes, including carcinogenesis, as well as developmental and psychiatric disorders, such as autism and schizophrenia.

DNA methylation in eukaryotes is mediated by the addition of a methyl group to the $\mathrm{C} 5$ position of cytosine residues. 5-Methyl-cytosine occurs most often at CpG dinucleotides and is generally associated with transcriptional silencing ( $\mathrm{Wu}$ and Zhang, 2014). DNA methylation is a

Received April 4, 2016; revised May 19, 2016; accepted May 20, 2016.

H.M. is a predoctoral fellow with a National Institutes of Health/National Institute of Neurological Disorders and Stroke Predoctoral Individual National Research Service Award type F31 (Grant NS084551).

The author declares no competing financial interests.

Correspondence should be addressed to Heather McGowan, Child

Health Institute of New Jersey, 89 French Street, Room 3233A, New Brunswick, NJ 08854.E-mail:mcgowahe@rwjms.rutgers.edu.

DOI:10.1523/JNEUROSCI.1130-16.2016

Copyright $\odot 2016$ the authors $\quad 0270-6474 / 16 / 366851-03 \$ 15.00 / 0$ dynamic and essential component of normal development, and contributes to fate determination as cells differentiate from pluripotency and through their progressively lineage-restricted progenitors (Feng et al., 2007). In a recent article, Sharma et al. (2016) attempted to define the overarching principles that direct the acquisition of DNA methylation over the course of neuronal development and subtype specification. They used bisulfite sequencing to investigate differentially methylated regions (DMRs) both "vertically" (i.e., through each developmental stage from stem cell to mature neuron) and "horizontally" (i.e., at each developmental stage between two distinct neuronal subtypes). DMRs were defined as regions that contained at least four differentially methylated sites within $1 \mathrm{~kb}$.

The authors defined five principles governing the methylation dynamics as neurons develop and mature. One principle was that differentially methylated genes are enriched in functional clusters that are regulated and expressed in a consecutive, stage-specific fashion. The remaining four principles describe the dynamic patterns that govern this stepwise progression through development, both within and between lineages. First, there were three shifts in the methylation patterns of cells during neuronal development. Initially, there was a period of hypermethylation during the transition from pluripotency to neural progenitors (Stage 1; Sharma et al.,
2016, their Fig. $1 B, D)$. As progenitor cells produced young neurons, there was a phase of hypomethylation (Stage 2; Sharma et al., 2016, their Fig. $1 B, D)$, and this was followed by another wave of hypermethylation during the transition from young to mature neurons (Stage 3; Sharma et al., 2016, their Fig. $1 B, D)$. These findings are consistent with those in the literature showing concurrent methylation and demethylation during neuronal differentiation (Lister et al., 2013), but by identifying the location of clustered sites showing bidirectional changes in methylation, which they assessed across development, Sharma et al. (2016) clarified these previous findings.

The second principle is that, in addition to the more typical CpG context, the hypermethylation that occurred during Stage 3 (i.e., the transition from young to mature neurons) was uniquely marked by the accumulation of methylation at $\mathrm{CpH}$ (where $\mathrm{H}$ is any nucleotide other than $\mathrm{G}$ ) dinucleotides, particularly in a CpA context. Sharma et al. (2016) again acknowledged studies that described increased $\mathrm{CpH}$ methylation in neurons (Ramsahoye et al., 2000; Lister et al., 2009; Harris et al., 2010; Ziller et al., 2011; Xie et al., 2012), but highlighted that their study specifies that $\mathrm{CpH}$ methylation in the brain is obtained after neurons become postmitotic. They additionally demonstrated that the Stage 3 gain in methylation is prevented by conditional knockdown of the de novo 
methyltransferase DNMT3a (Sharma et al., 2016, their Fig. $1 H$ ), which is crucial for $\mathrm{CpH}$ methylation. Sharma et al. (2016) are not the first to demonstrate this, however. Guo et al. (2014) determined via time-course analysis that de novo $\mathrm{CpH}$ methylation occurs postnatally during neuronal maturation, that nonCpG methylation in the brain occurs mostly in a CpA context, and that this is conserved in human brains. Using short hairpin knock-down experiments, they also concluded that this process depends on DNMT3a. Gabel et al. (2015) also recently demonstrated that $\mathrm{CpH}$ methylation is absent in Dmnt 3 a conditional null animals.

Interestingly, Guo et al. (2014) also found that methylated $\mathrm{CpH}$ sites could be recognized and bound by methyl-CpGbinding protein 2 (MeCP2), a DNA binding protein that recognizes methylated $\mathrm{CpG}$ sites, regulates transcription, and plays a crucial role in the maturation and function of neurons. Indeed, the affinity of MeCP2 for CpA sites in particular closely mirrors its binding affinity to symmetrically methylated CpGs. Given that dramatic increases in the expression of MeCP2 in neurons coincides with the accumulation of $\mathrm{CpH}$ methylation (Skene et al., 2010; Chen et al., 2015), and given the affinity of $\mathrm{MeCP} 2$ for $\mathrm{CpA}$ sites, the most common context for nonCpG methylation in neurons, it is plausible that $\mathrm{MeCP} 2$ may use these marks to regulate gene expression. In line with this, Chen et al., 2015 found that genes that acquire increased methylation at $\mathrm{CpH}$ loci postnatally become preferentially misregulated in mouse models of Rett syndrome (RTT; a neurodevelopmental disorder caused by mutations in $\mathrm{MeCP} 2$ ).

Together, this implies that the Stage 3 increase in methylation noted by Sharma et al. (2016), and particularly the largely neuron-specific acquisition of methylated $\mathrm{CpH}$ residues, may provide a regulatory signal for the developmentally appropriate recruitment of specific readers of DNA methylation to sites in the genome. This notion is also backed by the third principle of Sharma et al. (2016) that lineage-specific differences in methylation were minimal during Stages 1 and 2, but became substantial during the final stage of neuronal maturation. This was accompanied by disparate gene expression, with lineage-specific enrichment for genes pertinent to the distinctive functions of each subtype, which may reflect a shift in gene regulation mediated by the stage-specific changes in methylation context and their subsequent interpretation by regulators, such as MeCP2.

The fourth principle of Sharma et al. (2016) was that the changes in methylation during Stages 2 (i.e., hypomethylation) and 3 (i.e., hypermethylation; Sharma et al., 2016, their Fig. 3 E, F) occurred predominantly at introns and intergenic regions, and that several of these intronic DMRs had promoter/ enhancer activity, suggesting regulatory potential. They go on to highlight lineage-specific nuances, for example, how the Stage 2 loss of methylation was largely permanent in hippocampal cells, whereas many of these differentially methylated sites were remethylated in developing striatal cells during Stage 3 (Sharma et al., 2016, their Fig. 3C). This is consistent with their finding that striatal cells exhibited three to four times more methylated sites than hippocampal cells during neuronal maturation (Sharma et al., 2016, their Fig. $1 D$ ). This also potentially provides an avenue by which DNA methylation readers may contribute to the appropriate maturation and function of specific neuronal subtypes, as well as another potential etiological basis for disorder when these proteins are mutated or dysfunctional. For example, conditional deletion of MeCP2 from GABAergic interneurons recapitulates many RTT and autisticlike features in mice (Chao et al., 2010), and MeCP2 regulates the neuron-specific potassium-chloride cotransporter 2 (KCC2), which contributes to GABA dysfunction in RTT neurons (Tang et al., 2016). Given that there is a relative increase in methylation in GABAergic neurons compared with glutamatergic neurons (Kozlenkov et al., 2016), it is possible that this distinction may underlie the differential regulation of this protein among neuronal subtypes. However, further research is needed to build the connection between methylation marks and $\mathrm{MeCP} 2$ regulation in this instance.

The article by Sharma et al. (2016) provides a detailed look at the dynamic gains and losses in methylation across development and across neuronal subtypes. The framework Sharma et al. (2016) have laid out is supported not only by the quality of their work, but also by a large body of literature. In addition to contributing to our understanding of how changes in methylation contribute to the development and specification of neurons, Sharma et al. (2016) have also contributed to an evolving story of how epigenetic regulation contributes to neurodevelopmental disease.

\section{References}

Chao HT, Chen H, Samaco RC, Xue M, Chahrour M, Yoo J, Neul JL, Gong S, Lu HC, Heintz N, Ekker M, Rubenstein JL, Noebels JL, Rosenmund C, Zoghbi HY (2010) Dysfunction in GABA signalling mediates autism-like stereotypies and Rett syndrome phenotypes. Nature 468:263-269. CrossRef Medline

Chen L, Chen K, Lavery LA, Baker SA, Shaw CA, Li W, Zoghbi HY (2015) MeCP2 binds to non-CG methylated DNA as neurons mature, influencing transcription and the timing of onset for Rett syndrome. Proc Natl Acad Sci U S A 112:5509-5514. CrossRef Medline

Feng J, Fouse S, Fan G (2007) Epigenetic regulation of neural gene expression and neuronal function. Pediatr Res 61:58R-63R. CrossRef Medline

Gabel HW, Kinde B, Stroud H, Gilbert CS, Harmin DA, Kastan NR, Hemberg M, Ebert DH, Greenberg ME (2015) Disruption of DNA-methylation-dependent long gene repression in Rett syndrome. Nature 522:89-93. CrossRef Medline

Guo JU, Su Y, Shin JH, Shin J, Li H, Xie B, Zhong C, Hu S, Le T, Fan G, Zhu H, Chang Q, Gao Y, Ming GL, Song H (2014) Distribution, recognition and regulation of non-CpG methylation in the adult mammalian brain. Nat Neurosci 17:215-222. CrossRef Medline

Harris RA, Wang T, Coarfa C, Nagarajan RP, Hong C, Downey SL, Johnson BE, Fouse SD, Delaney A, Zhao Y, Olshen A, Ballinger T, Zhou X, Forsberg KJ, Gu J, Echipare L, O'Geen H, Lister R, Pelizzola M, Xi Y, et al. (2010) Comparison of sequencing-based methods to profile DNA methylation and identification of monoallelic epigenetic modifications. Nat Biotechnol 28:1097-1105. CrossRef Medline

Kozlenkov A, Wang M, Roussos P, Rudchenko S, Barbu M, Bibikova M, Klotzle B, Dwork AJ, Zhang B, Hurd YL, Koonin EV, Wegner M, DrachevaS (2016) Substantial DNA methylation differences between two major neuronal subtypes in human brain. Nucleic Acids Res 44:2593-2612. CrossRef Medline

Lister R, Mukamel EA, Nery JR, Urich M, Puddifoot CA, Johnson ND, Lucero J, Huang Y, Dwork AJ, Schultz MD, Yu M, Tonti-Filippini J, Heyn H, Hu S, Wu JC, Rao A, Esteller M, He C, Haghighi FG, Sejnowski TJ, et al. (2013) Global epigenomic reconfiguration during mammalian brain development. Science 341: 1237905. CrossRef Medline

Lister R, Pelizzola M, Dowen RH, Hawkins RD, Hon G, Tonti-Filippini J, Nery JR, Lee L, Ye Z, Ngo QM, Edsall L, Antosiewicz-Bourget J, Stewart R, Ruotti V, Millar AH, Thomson JA, Ren B, Ecker JR (2009) Human DNA methylomes at base resolution show widespread epigenomic differences. Nature 462: 315-322. CrossRef Medline

Ramsahoye BH, Biniszkiewicz D, Lyko F, Clark V, Bird AP, Jaenisch R (2000) Non-CpG methylation is prevalent in embryonic stem cells 
and may be mediated by DNA methyltransferase 3a. Proc Natl Acad Sci U S A 97:52375242. CrossRef Medline

Sharma A, Klein SS, Barboza L, Lohdi N, Toth M (2016) Principles governing DNA methylation during neuronal lineage and subtype specification. J Neurosci 36:1711-1722. CrossRef Medline

Skene PJ, Illingworth RS, Webb S, Kerr AR, James KD, Turner DJ, Andrews R, Bird AP (2010) Neuronal MeCP2 is expressed at near histoneoctamer levels and globally alters the chroma- tin state. Mol Cell 37:457-468. CrossRef Medline

Tang X, Kim J, Zhou L, Wengert E, Zhang L, Wu Z, Carromeu C, Muotri AR, Marchetto MC, Gage FH, Chen G (2016) KCC2 rescues functional deficits in human neurons derived from patients with Rett syndrome. Proc Natl Acad Sci U S A 113:751-756. CrossRef Medline

Wu H, Zhang Y (2014) Reversing DNA methylation: mechanisms, genomics, and biological functions. Cell 156:45-68. CrossRef Medline
Xie W, Barr CL, Kim A, Yue F, Lee AY, Eubanks J, Dempster EL, Ren B (2012) Base-resolution analyses of sequence and parent-of-origin dependent DNA methylation in the mouse genome. Cell 148:816-831. CrossRef Medline

Ziller MJ, Müller F, Liao J, Zhang Y, Gu H, Bock C, Boyle P, Epstein CB, Bernstein BE, Lengauer T, Gnirke A, Meissner A (2011) Genomic distribution and inter-sample variation of non-CpG methylation across human cell types. PLoS Genet 7:e1002389. CrossRef Medline 